like, and acceptable as possible; and yet it is quite possible $/$ into the hidden causes of things, stronger proofs can be ob- $/$ chance, at first sight seem very hard to be received, yet I that it may convey the elements of truth as really as many a tained from reliable experiments and demonstrated urgu- $\begin{aligned} & \text { doubt not but that at length they will obtain authority from } \\ & \text { the clear proofs given. Wherefore, in magnetic science, }\end{aligned}$ and grotesqurious philosopical on it tends to bring out new features and aspects of it which might be overlooked in the ordinary light of scientific Aud there is another point of view in which some might be dispnsed to regard it favorably. If not in accordance mony with the older and orthodox ideit of the personality of God. It strikes the same key-note of impersonation, and is
in accordance with the style of language emploved in the in accordance with the style of language emploved in the ( of expression still made use of, and still most readily undertions in the world.

\section{[THE AsCLEPIAD.]}

THE FIRST ELECTRICIAN-WILLIAM GILBERT, M.D.

By Benjamin Ward Richardson, M.D.

IF there be one old town in England more interesting than another to the historical scholar, it is Colchester. Every
class of scholar may tind some interest there, and we of class of scholar may find some interest there, and we of
medicine need not be behind the rest. In Colchester we shall find the birthplace and the final resting-place of the city, and the first true idea of the power. The pioneer in question was William Gilbert, M.D., friend and favorite physiciun of Queen Elizabeth.

The best account of this man is supplied in " The History and Antiquities of the Most Aucient Town and Borough of Colchester," by Philip Morant, M.A. MDCcXLvirr

Hieron (Jerome) Gylberd gentleman, a ne was the son of in Suffolk, but afterward a burgess of Colchester: made so in 1528. William was born in the year 1540. He studied both in Oxford and Cambridge, and afterward traveled on the Continent, where (according to Morant) be had con-
ferred upon him the degree of Dontor of Physic. Dr. Munk, howerer, has gathered from Mr. Cooper, the learneri author of the "Athenæ Cantabrigienses," that he was of St. John's elected fellow of St. John's, 21st March, 1560-61; M.A.
1564; M.D. 1569; and senior fellow o! his college 21 ist December, 1569.

Gilbert settled in London when he was thirty-three years
of age, and commenced practice as a physician. He became a Felliw of the Royal College of Physicians, passed througb the office of Censor and Elect, and in the year 1600 was inade President.

That he practiced his profession with great success is clear from the evidence of all who have written concerning him. He was received, says Morant, with the highest favor by
Queen Elizabeth, whom be served as chief physician, and from whom he received a legacy, the only legacy she lef to any one. He also, for the short period between the Uaeen's death and hil own, acted as physician-in-chief to $v$ et of minerals to the College of Phssiciaus. Morrant states that there was a portrait of Gilbert in the
Schools Gallery at Oxford in his time, which portrait showed Schools Gallery at Oxford in his time, which portrait showed
him to bave been tall of stature and of cheerful countenance. him to bave beentall of stature and of cheerful countenance.
It is from this portrait that the engraving on this page was probably taken, although we have now no direc for autotye copy by permission of the Treasurer of $\mathrm{me}$ Royal College of Physicians.

From this plate as the center of the subject, Mr. Artbu Ackland Hunt produced, a few years ago, a very fine bistorical painting, representing Gilbert making in experimental
demonstration in electricity, before Queen Elizabetb. In the picture Sir Walter Raleigh, Drake, and Burleigh contrast admirably with the ladies of the Court, who, if I remember rightly, are more interested in a young courtier than in the experiment.
Gilbert's bouse in Colchester was anciently called “ Tymperley's" or Tympornell's. In Morant's time it " was the same as Serjeant Price, late Recorder, lived in, and stil possessed by bis widow and relict. Bridget Price"

but that he had every facility for his own line of reserd there cannot be reasonable donbt. To that research, so rebearings, I now direct, briefly, the attention of the reader. The peculiarity of the work which first strikes us lies in a
word. Gilbert is the man who gave to us the word electriciword. Gilberl is the man who gave to us the word electrici-
tas. It bad been known, long before his time, that the rubbing of amber (electron) cinsed amber to at tract some ligh
bodies. Gilhert whose great line of investigation was on the magnet, differentiated between the attraction exerted by the maguet and that cxerted by the excited amber. He counecled also the kind of attraction evidenced through amber
with that produced by exciting glass, wax, jet, and nther substances since known as electrics. His great work "De Mag
nete," published in 1600, becomes thus the basis of all our nete," published in 1600 , becomes thrs the basis of all our
electrical science from that date. Galileo, Bacon, 'Thomson the historian of the Royal Society, Priestley, and in our later
time Hallam, all bear witness to the solid quality and originality of the De Magnete. For preparing this short memoir I have, with the kind as-
sistance of my friend Mr. James Menzies, made a study of this book, snme portions of which are sure to be of interest
to all scientific and medical readers. student of magnetic philosophy, a preface so good that it
admits, scarcely, of curtailment. In it Gilbert pours forth the spirit of true philosopty. In it he shows that be wus
well acquainted with and a master of the experimental method of research is natural science. In it he demonstrates
that be was actually carrying out, in practice, that which the author of tlie Novum Organon - wbo, upon natura was putting on paper as a series of speculative disquisitions and projects.

called the father of modern experimental science. With Mr. Menzies' kind and learned aid I give this remarkable pre
lish dress.

PREFACE TO THE CANDID READER AND STUDENT OF MAGNETIC PHILOSOPHY.

"Since in the discovery of the secrets, and in the inquiry famous substanee of that great magnet, our common mother and eminent forces of this globe of surs, may be the better understood I propose to begin from the common the better arthy, and iron bodies, those substancesof our globe which we can grasp with our hands and perceive with our senses so penetrate, for the tirst time, in to the innermost parts and
ecrets of the eartb. For after very many of those things ecrets of the eartb. For after very many of those things
which have been obtained from the heights of mountains, the depths of seas, the profouudestcaverns and buried mines earnt the true substance of the earth. To the investigalion of magnetic force (such, indeed, are the wonderful and surpassing qualities of the bodies known to us) bave I given a great and prolonged attention. Nor bave 1 found this labor idle and unfruitful, inasmuch as during the progress of my
daily experiments, new and unexpected properties bave re-

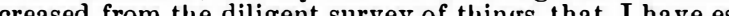
sayed to show forth the very interior of ibe terrene globe and its true substauce on magnetic principles; to reveal unto men the earth (our cominon mother), and to point it ou
as with the finger, by true demonstrations, and by experi-

"And as geometry ascends from sundry very simple and which the wit of man climbs above the firmament, so our teaching of magnetic science first sets forth in convenien order certain obvious facts; out of these more remarkable nd greatest secrets of our globe are opened, and the causes f ancient, or the neglect of racent, times, have benace

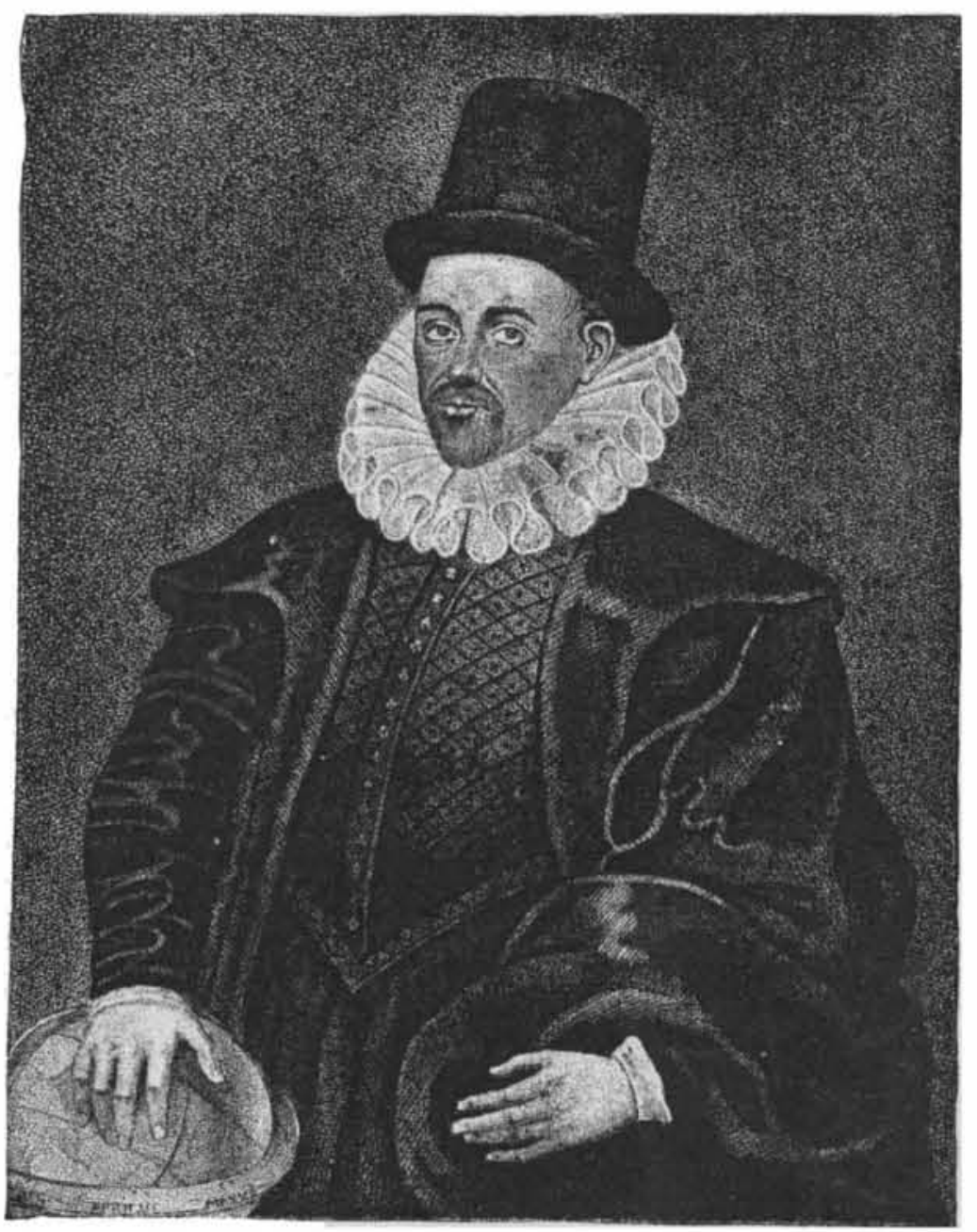

WILLIAM GILBERT, M.D.-ELECTRICIAN.

looked and unknown. But why should I, in so vast an
ocean of books, by which the minds of ingenious men are ocean of books, by which the minds of ingenious men are
roubled and fatigued, through which very silly productions he berd of unreasoning men are intoxicated, rave, are puffed to be philosophers, physicians, mathematicians, and astrologers, neglect and despise men of learning; why should I, I
say, add anything new to this republic of letters, and expose his philosophy, glorious, seemingly new and incredible, on account of so many things hitherto unrevealed, to be con-
demned and torn to pieces by the ill words of such persons ish corrupters of good arts, bookish laymen, or grammarians, sophists, wranglers, and froward individuals of the meanes: kind? But unto you almost alone, you bonest students of philosophy, who seek knowledge not from bons only, hut
from things themselves, I commend these principles of magrom things themselves, I commend these principles of mag-
aetism, set forth in a new mode of philosophizing.

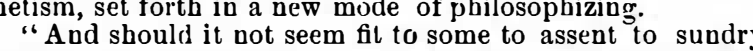
pinions and incredible statements, lhey may nevertheles (such as all philosophy ever flourisheth in), which have been searched out and demonstrated by me with much care, watchfulness, and cost. In them rejoice, and to good pur-
pose enjoy them, if ye be able. I know how difficult it is o give freshness to old things, brilliancy to the antiquated,
light to the dark, grace to the despised, credibility to the light to the dark, grace to the despised, credibility to the
doubtiul; how much more difficult is it to obtain and estab lish some authority for things new and unheard of, and howe-ver, do I care; since I think it is to few that the phiosophic spirit hath been voucbsafed. Whoever desires to make trial of the same experiments, let him handle the subiu a business-like way and let him not (when be fails of and cess) begin to find fault with $\mathrm{m}$ y inventions, for nothing sucbeen $s: t$ forth in this book which bath not been examined nd many times tried and repeated by me. lso, had they been to light very many facts which they

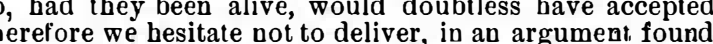
ed on truth, those things which have been discovered by us

THE BOOK

Such is the preface to this wonderful book. Its first chap ter supplies a description of the magnet and of magnetic and the power electricity. It explains that not only will other thet attract some bodies brought near to it, but som by friction. Amber (elearon) is one of the substances wlich can be thus excited; jet is another of the same kind; but "orty "Amber," Gilbert says, "holds flies, ants, and othe shall creatures shining in eternal sepulchers"-aternis sepu
chris relucentes. There was a touch of poetry in William The bodies of this nature may, then, be called electric and tine property they present may be called the electric, or electrical. There are many bodies which act as elect rics, ome other precious stones, glass, sulphur, mastic, sealingome other precious stones, glass, sulphur, mastic, sealingGilbert seems to have discovered that glass, sulphur, and wax are electrics, lis mode of discovery being as simple as it was effertive. Smallstrips of metal suspended from their was presented, and the attraction was the proof of the elec-

He was very exact in noting the conditions under which s always most active when theair is dry and when the wind even the presence 
an electrified body to drops of water, produced a conical
sbape in the round drop. He under our diligent scrutiny everywbere shows itself, fied rod were brought burning substance, tbe smoke was attracted. He suggested
that electricil attraction was due to the electrical fluid or effluvium rusbing from one substance to anotber of similar kind, and cobering, as two drops of water cobere and run
into one. He suggested also, on this matter, a distinction into one. He suggested also, on this matter, a distinction tbat all magnetic bodies attract by their mutual strength, wbile in electric bodies tbe electric attracts only; the body attracted is not changed by its natural force, but is drawn
spontaneously by the nature of the material of which it is spontaneously by the nature of the material of which it is
composed. Bodies are drawn toward electric bodies in composed. Bodies are drawn toward electric bodies in a
straight line toward the center of electricity; but the magstraight line toward the center of electricity; but the mag-
net attracts the magnet only at the poles directly, at otber points obliquely and transversely, even as they adhere and bang togetber. Electric motion is the motion of au accumulation of matter; magnetism, of arrangement and order. The globe of the earth is collected, and colleres by electricity.
The globe of the earth is directed and moves by magnetism, and at the same time it also coleres and is welded togetber

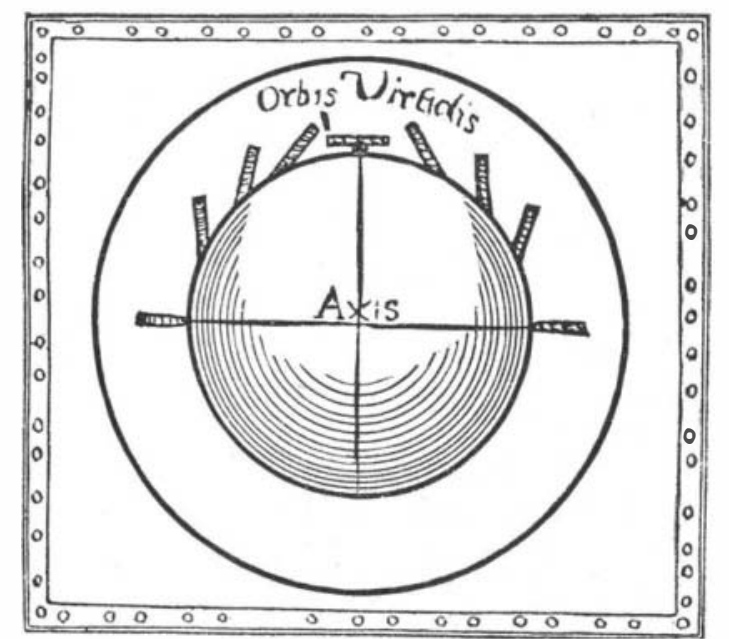

Eig. 1.

To these remarkable indications must be added, however, otbers as remarkable in respect to the magnet. There is electrical properties of the earth and the attraction of the planet for substances uporitits surface. He gives a drawing (Fig. 1), of wbicb I present a copy, in wbich he depicts a
magnetic globe or orb, and indicates how magnetic poles or magnetic globe or orb, and indicates bow magnetic poles or bars arrange tbemselves in respect to the axis of the globe.
One of the most interesting chapters on this matter of terOne of the most interesting chapters on this matter of ter-
restrial magnetism is chapter xvii. in hook i., "Quod

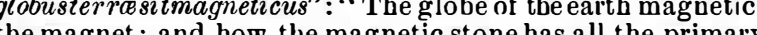
the magnet: and how the magnetic stone has all the primary forces maintains its fixed position in the universe." "This cbapter begins:

"Before the cause of magnetic motions, the demonstration of facts concealed during so many ages, and experiments (tbose true foundations of buman pbilosopby) are brougbt to
light by us, tbat new and unheard of opinion of ours must he stated and laid before the eyes of the learned; whicb, when it bas been debated and supported by certain probable reasons, it will indeed be establisbed as firmly as anything
w lich bath ever been seen or proved in philosophy by ingenious arguments or matbematical demonstrations." Gilbert's opinion, thus prefaced, is, that tbe earth witb its
masses of rock and water, and allits parts, wbetber seen or

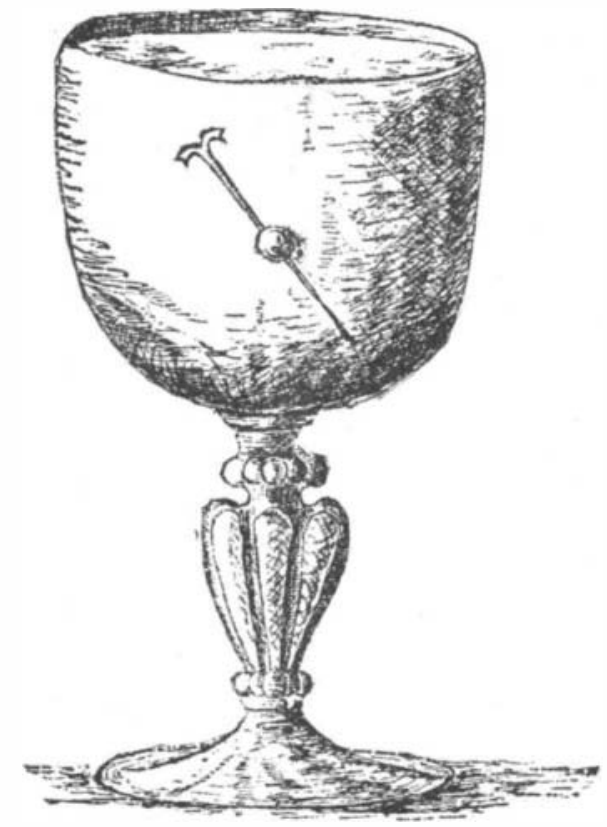

FIG. 2.

hidden from human sight, is a magnet, and is possessed of "the earth to be a solid substance, firmly colsering in its primary form, and (as in the other globes of the universe) endowed with a well knit form, which maintains its position from an implanted power of movement, even as the magnet,
beyond all bodies seen by us, possesses a true and genuine cbaracter, little injured and deformed by external evils, cbaracter, little injured and deformed by external evils,
which is a bomogeneous and true part of, and wbicb bas which is a bomogeneous and true part of, and whicb
been separated from, the body and volume of the earth. "Sucb is our earth in its interior parts, a body possessing
a bomogeneous magnetic nature; and on such a perfect
Latiption. which my learned brother Munk l,as coni-
ed into his Roll of tbe Royal Collegeof Pbysicians, and which foundation stands the whole nature of terrestrial things, I supplement in Englisb: such as in all the magnetic metals of the earth, in veins of
iron, in all kinds of clay, and in most varieties of earth and iron, in all kinds of clay, and in most varieties of earth and
stone; whereas the pure element of Aristotle, and the main stone; whereas tbe pure element of Aristotle, and tbe main
terrestrial pbantasm of the peripatetic plilosophers (tbat
simple substratum of all tbings) is rude, inert, cold, dry. simple substratum of all tbings) is rude, inert, cold, dry,
dead, of no vigor, bath never appeared to any one except in dreams, and is of no effect in the nature of tbiugs. To
sneak plainly, all the solid earth, wherever it is seen; even and bumid elements, sucb as clay, mire, and material gatland bumid elements, sucb as clay, mire, and material gathed by the inperfection of various mixtures, or fallen to
pieces through their grossuess like marl, all tbese, whether they bave been prepared by fire alone, or are freed from their superfluous moisturc, are attracted by the magnet, and as by the magnet so also are other bodies magnetically attracted
and set in order by the earth itself; and through tbeir implanted force do they arrange themselves according to the method and order of tbe world. So also every fragment of the eartb, by true experiment, shows all tbe force of the ple of our earth throughout its various motions."
In

In another part of bis work be gives the preceding dia gram to sbow how a needle, floated by means of a cork in a be rendered maguetic (Fig. 2).

In cbapter xii., book $i$., he compares magnetic force to
vital force. Magnetic force is life or resembles life, and surpasses buman life in many respects, while it is bound it the organic body.

and is, at it were, a living force. This is the one rements able virtue of those which the ancients considered ton be life in the heavens, in globes and stars, in the sun and moon.
For they considered that such varied motions could not be maintained witbout a divine and living force; or that with-
out it, vast bodies could revolve in fixed terms, or that wonout it, vast bodies could revolve in fixed terms, or that won-
derful powers could be infused into other bodies tbrougl, terf primary form of tbe globes tbemselves. The ancients,
tbe whole Platonic school, the Egyptians. affirm that the universe is endowed with life. On the other band, Aristotle thinks tbat tbe elements are inanimate, the stars animate. I myself think that the whole creation, al globes, all stars, and the glorious eartb itself, are governed
from the beginning by a proper and determinate life, and from the beginning by a proper and determinate life, and
have their movements of self-preservation. Altbough there

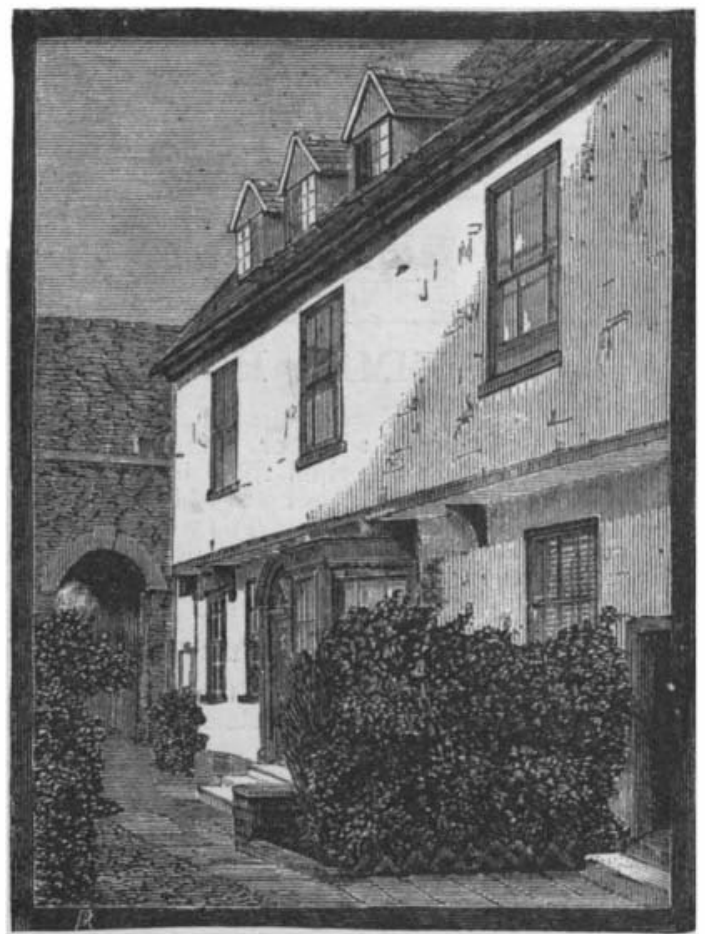

GILBERT'S HOUSE AT COLCHESTER
ANBROSE AND WILLIAM G IJBERD HAVE PLACED THIS TOMB,
IN MEMORY OF BROTHERLY PIETY,
TO WILLIAM GILBERD, SENIOR, GHNTLENAN, AND DOCTOR O THIS THE ELDEST SON MEDICINE. GILBERD, GENTLEMAN, STTDIED THE ART OF MEDICINE AT CAMBRIDGE,
ICED THE SAME FOR MORE THAN THIRTY YEARS AT LONDON, WITH SINGOLAR, CREDI'T AND SUCCESS,
HENCE, CALLED TO COURT, HE WAS RECEVFD WITH HIGHEST FAVOR BY QUEEN ELIZABETT,
TO WHOM, AND TO HER SUCCESOH JAMES, HE SERVED AS CHIE HE COMPOSED A BOOK CEYEBRATED AMONG FOREIGNERS
CONCENING TYE MAGNET, FOR NAUTICAL SCTENCE.

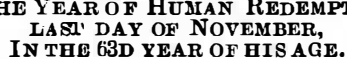

The monument bearing the above epitanh remains in fai reservation in the old church of the Holy Trinity; and riend Henry Laver, of Colchester, surgeon tbere, and ex cellent antiquarian scholar, to whom I am much indebled, wich view Bertram Richardson the residence as it now is, fitting conclusion to tbis short bistory of First Electrician. DETECTION AND DETERMINATION OF PICRIC ACID.

By G. Christel.

THrs compound forms yellowisb white leaflets which take up ammonia on exprosure to the air and assume a deep yel-
low color. The solutions of trinitrophenol in dilute acids, low color. The solutions of trinitrophenol in dilute acids,
in cbloroform, and carbon disulpbide are colorless. If the mains a colorless rcsidue whicb is colored deep yellow by a drop of water. If a yellow (ammoniacal) picric acid is dis-
solved in a little water, mixed with two or three volumes of
either and shaken up, a wartonly of the acid is taken up by eitber, and shaken up, a partonly of the acid is taken up by the etber, and further additions of etber dissolve scarcely
any coloring matter. The addition of acctic acid does not alter tbis bebavior, but after adding a little sulphuric acid A entire picric acid may be extracted with ether and tbe golden-yellow ammonium picrate is insoluble in ether. Chloroform removes only a part of picric acid from its pure watery soluticn or from one which bas been acidulated witb sulpburic acid. In searching for picric acid it is tbere-
fore best to acidulate witb sulpburic acid and exhaust by ore best to acidulate witb sulpburic acid and exhaust by
shaking up with ether. If to a solution of picric acid or ammonium picrate in wate
we add neutral leald acetate or copper sulphate no precipitate, but on furtber adding a little alkali (ammonia) there is formed with lead acetate a reddish yellow precipi-
tate, and with copper sulphate a greenish precipitate. On tate, and wilh copper sulphate a greenish precipitate. On
the other band, $\frac{1}{20}$ milligramme picric acid dissolved in strongly opalescent, and gives subsequently a slight but
distinct yellow precipitate Tlus precipitate is decomposed by dilute sulphuric acid. If the same precipitate is sub-
mitted to prolonged treatment with water, a part of the picric acid is clissolved, while there remain an apparently more basic compound of a deep orange-yellow.
The yellow coloring-matters of Quercus tinctoria (quercitron bark) and of Bronssonetia tinctoria (fustic) behave in coloring matters are distinguished from ricric acid gous they are neither changed by potassium cyanide nor reduced by potassium stannite. Their precipilates are never so pale yellow as that of picric acid. The soluble aniline yellow of
commerce dissolves to a reddisb yellow liquid which if much diluted appears of a pure yellow. It is very imperfectsium cyanide, but turned at once to a purple by bydrochloric acid. If a solution of trinitropbenol, not too ditute, is mixed green precipitate whicb in excess of water dissolves to a bluisb acids. Witb organic bases (alkaloids) picric acid gives preseparation. On boiling solutions of picric acid with permanganate, considerable quantities of the latter are reduced.
If to an aqueous solution of picric acid there is added stan-
nous chloride, a vellowish brown precipitate falls down nous chloride, a yellowisb brown precipitate falls down,
but if a little ammonia be added, or if potassium stannite is but if a little ammonia be added, or if potassium stannite is
used, the liquid becomes red from the formation of picramic used, the liquid becomes red from the formation of picramic
acid. If to a solution of barium chloride there are added a
few crystals of caustic baryta and a solution of picric: acid. not too dilute, there is formed a red precipitate. Sulphureled same effect is rapidly produced by ammonium sulphide. By the action of zinc and dilute sulphuric acid upon picric acid there is formed a yellowish red turbid liquid. If this is de-
canted off from the zinc, mixed with an excess of alcobol canted off from the zinc, mixed with an excess of alcobol
(ethylic), allowed to stand for some time, and filtered, the liquid becomes greenish, and changes first to a violet blue and tben to a reddisb violet. If even a very small quantity of picric acid (much less than 1 milligramme) or of an alkaline picrate is beated with hydrocbloric acid and stannous chlo-
ride, allowed to cool, a trace of potassium chlorate added to ride, allowed to cool, a trace of potassium chlorate added to
the mixture slightly heated the liquid becomes first greenthe mixture slightly beated, the liquid becomes first greensence of poranic matter this reaction is not distinct preof the most sensitive and trustworthy reactions is the wellknown transformation of picric acid into red phenylpurpuric acid on heating with potassium cyanide. Trinitiocresol, in like manner, forms cresylpurpuric acid on treatment with potassium cyanide. If an aqueous solution of picric acid, not quite saturated, is mixed with potassium sulpbocyanide
and tbe mixture beated, there appear in the liquid (wbich at first remained clear) numerous yellow crystalline peedles which reflect incident ligbt with splendid green and red colors. If the crystals are separated from the liquid, dried, and touched with an incandescent body, they explnde witb
extreme violence. Nitrogenous tissues (wool, silk) take permanent yellow in an aqueous solution of picric acid; ab-
solute alcohol, hydrocbloric acid, dilute caustic aikalies, and aqueous ammonia withdraw the picric acid, partially or entirely, from such tissues. Tbe residue from the evaporation of the ammoniacal solution tbus obtained is particularly
fitted for the basic acetate of lead reaction and for that with potassium cyanide. Animal charcoal, if added in small quantities $t_{1}$ a solution of picric acid, does not decolorize it, but larger quantities entirely withdraw picric acid from its
solutions. To detect picric acid in beer Christel evaporates $200 \mathrm{c}$. c to the consistence of a sirup; introduces the residue into a
small flask, alds $50 \mathrm{c}$ c. of alcobol at 90 per cent., lets it
stand for tweuty-four hours, during which the whole is re- 